American Journal of Applied Sciences 9 (2): 227-230, 2012

ISSN 1546-9239

(C) 2012 Science Publications

\title{
Investigation of the Critical Clearing Time of Power System with Synchronous Machine Model Including Saliency
}

\author{
Prechanon Kumkratug \\ Division of Electrical Engineering, Faculty of Engineering at Si Racha, \\ Kasetsart University, 199 M.6, Tungsukhla, Si Racha, Chonburi, 20230, Thailand
}

\begin{abstract}
Problem statement: Most of synchronous generator applied in power system is the salient pole type. Most of previous researches use non-salient model to evaluate the critical clearing time. Thus the results of critical clearing time of power system may be error. Approach: Thus this paper investigate the critical clearing time of power system with synchronous machine. The mathematical model of non-salient pole and salient pole synchronous machine model in power system are symmetrically derived. The critical clearing time of both models are tested and compared on various cases. Results: The critical clearing time of the power system with synchronous including saliency is slightly higher that of non saliency model. Conclusion: It is found from simulation results that even swing curve of both models is obviously different. Their critical clearing times are slightly different.
\end{abstract}

Key words: Power system stability, transient stability, critical clearing time, FACTS devices, salient pole, non-salient pole

\section{INTRODUCTION}

From the energy utilization point of view, electricity is still being regarded as mighty means of energy carrier. Nowadays, the demand of electricity has dramatically increased and a modern power system becomes a complex network of transmission lines interconnecting the generating stations to the major loads points in the overall power system in order to support the high demand of consumers. The complicated network causes the stability problem. Currently, power engineers are much more concerned about stability problem due to blackout in Northeast United States, Scandinavia, England and Italy (Kumkratug, 2010; Osuwa and Igwiro, 2010; Santos et al., 2010). They have proposed many methods to improve stability of power system such as load shedding, Flexible AC Transmission System (FACTS), (Al-Husban, 2009; Darabi et al., 2008; Kumkratug, 2011; Magaji and Mustafa, 2009; Taher et al., 2008; Zarate-Minano et al., 2010).

The evaluation of Critical Clearing Time (CCT) of power system is one of the most important research areas for power engineers because it indicates the robustness of the faulted power system. The dynamic behavior of synchronous generator plays very important role to determine the CCT of power system. There are two type of synchronous machine; salient pole and non-salient pole. Many previous researches use synchronous generator excluding saliency. Thus it is very interesting to investigate the effect of salient pole of generator whether it affects on the CCT or not.

This paper investigated the critical clearing time of the system equipped with different types of synchronous generator. The mathematical model of non-salient pole and salient pole synchronous machine model in power system are symmetrically derived. The critical clearing time of both models are tested and compared on various cases.

\section{MATERIALS AND METHODS}

Mathematical model: Figure 1a shows the single line diagram of power system. First consider the non-salient pole model of generator equipped in power system as can be shown in Fig. 1b. Here $\mathrm{X}_{\mathrm{L}}$ is the equivalent reactance of each transmission line. The generator is represented by a synchronous voltage in quadrature axis $\left(\mathrm{E}_{\mathrm{q}}^{\prime}\right)$ behind direct transient reactance $\left(\mathrm{X}_{\mathrm{d}}^{\prime}\right)$. The $\mathrm{V}_{\mathrm{b}}$ is the voltage at infinite bus. Fig. 1c is the equivalent reactance circuit of Fig. 1b. Here $X_{1}$ is equivalent circuit of transmission line $L_{1}$ and line $L_{2}$ whereas $X_{2}$ is equivalent circuit of transmission line $\mathrm{L}_{3}$ and line $\mathrm{L}_{4}$. The dynamic equation for evaluating critical clearing tine is given by Eq. 1 and 2:

$\dot{\delta}=\omega$ 
Am. J. Applied Sci., 9 (2): 227-230, 2012

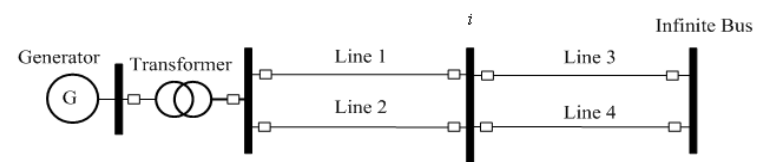

(a)

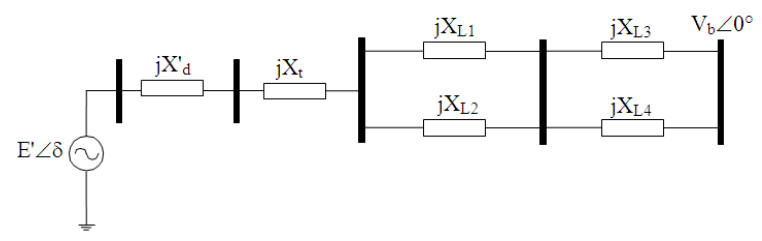

(b)

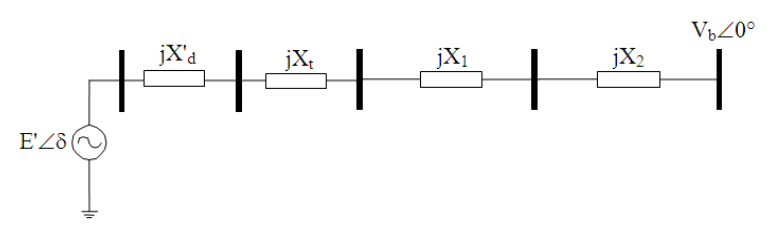

(c)

Fig. 1: Single machine infinite bus system (a) schematic diagram (b) equivalent circuit (c) net series reactance diagram

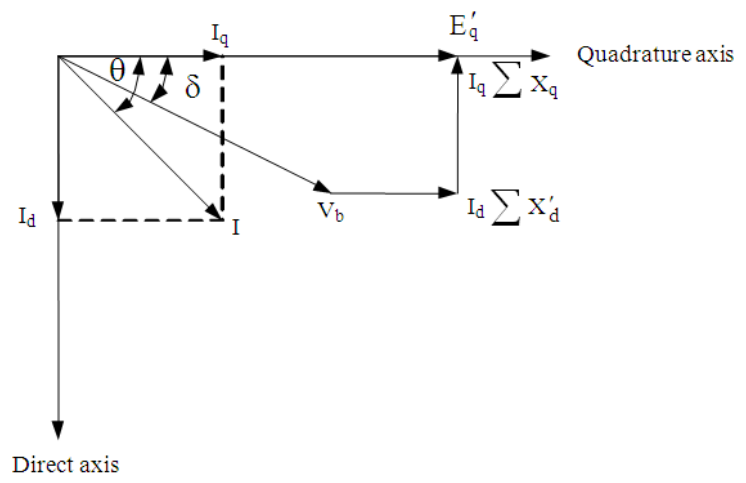

Fig. 2: Phasor diagram

$\dot{\omega}=\frac{1}{\mathrm{M}}\left[\mathrm{P}_{\mathrm{m}}-\mathrm{P}_{\mathrm{e}}\right]$

The $\delta, \omega$ and $\mathrm{P}_{\mathrm{m}}$ in (1)-(2) are the rotor angle, speed, mechanical input power and moment of inertia, respectively of synchronous machine.

The output electrical power of synchronous machine $\left(\mathrm{P}_{\mathrm{e}}\right)$ excluding saliency is given by Eq. 3 :

$\mathrm{P}_{\mathrm{e}}=\frac{\mathrm{E}_{\mathrm{q}}^{\prime} \mathrm{V}_{\mathrm{b}}}{\sum \mathrm{X}_{\mathrm{d}}} \sin \delta$

Here $\sum X_{d}$ is the net equivalent reactance of the system in direct axis and given by Eq. 4 : $\sum X_{d}=X_{d}^{\prime}+X_{t}+X_{1}+X_{2}$

Here let consider the synchronous machine in salient pole type. Figure 2 shows the phasor diagram of power system with synchronous machine including saliency.

Here I is the generator current at terminal and it is consist two component; direct axis and quature axis as given by Eq. 5 and 6 :

$I_{q}=I \cos \theta$

And:

$I_{d}=I \sin \theta$

The synchronous voltage in quadrature axis is given by Eq. 7:

$\mathrm{E}_{\mathrm{q}}^{\prime}=\mathrm{V}_{\mathrm{b}} \cos \delta+\sum \mathrm{X}_{\mathrm{d}} \mathrm{I}_{\mathrm{d}}$

The output power of generator is given by Eq. 8:

$\mathrm{P}_{\mathrm{e}}=\mathrm{V}_{\mathrm{b}} \mathrm{I} \cos \theta$

From the (5), (6) and (8), the output power of generator is given by Eq. 9 and 10:

$\mathrm{P}_{\mathrm{e}}=\mathrm{V}_{\mathrm{b}}\left(\mathrm{I}_{\mathrm{q}} \cos \delta+\mathrm{I}_{\mathrm{d}} \sin \delta\right)$

From Fig. 2:

$\mathrm{V}_{\mathrm{b}} \sin \delta=\sum \mathrm{X}_{\mathrm{q}} \mathrm{I}_{\mathrm{q}}$

Here $\sum \mathrm{X}_{\mathrm{q}}$ is the net equivalent reactance of the system in quadratur axis and given by Eq. 11:

$\sum X_{q}=X_{q}+X_{t}+X_{1}+X_{2}$

From (7) and (10), the $I_{d}$ is given by Eq. 12:

$\mathrm{I}_{\mathrm{d}}=\frac{\mathrm{E}_{\mathrm{q}}^{\prime}-\mathrm{V}_{\mathrm{b}} \cos \delta}{\sum \mathrm{X}_{\mathrm{d}}}$

The output power of synchronous generator including saliency is given by Eq. 13:

$P_{e}=\frac{E^{\prime} V_{b}}{\sum X_{d}} \sin \delta+V_{b}^{2} \frac{X_{d}^{\prime}-X_{q}}{\sum X_{d} \sum X_{q}} \sin 2 \delta$ 


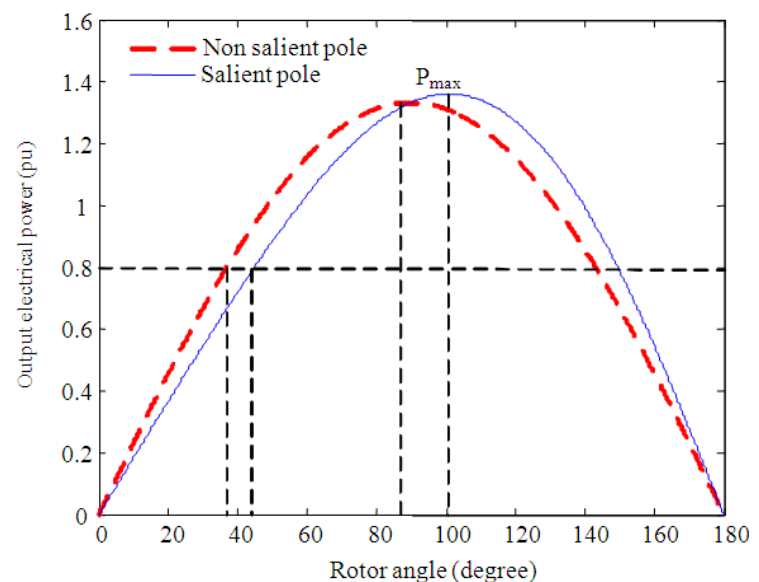

Fig. 3: Power curve of synchronous machine

It is well known that the power curve $\left(\mathrm{P}_{\mathrm{e}}-\delta\right)$ provides very important information of analyzing the critical clearing time of power system. Figure 3 shows the swing curve of the sample system as shown in Fig. 1a.

The system parameters are:

$\mathrm{H}=5, \mathrm{X}_{\mathrm{t}}=0.1 \mathrm{pu}, \mathrm{X}_{\mathrm{d}}^{\prime}=0.25 \mathrm{pu}, \mathrm{X}_{\mathrm{q}}=0.6 \mathrm{puX}_{\mathrm{L} 1}=0.5 \mathrm{pu}$, $\mathrm{X}_{\mathrm{L} 2}=0.5 \mathrm{pu}, \mathrm{X}_{\mathrm{L} 3}=0.5 \mathrm{pu}, \mathrm{X}_{\mathrm{L} 4}=0.5 \mathrm{pu}, \mathrm{P}_{\mathrm{m}}=0.8 \mathrm{pu}$, $\mathrm{E}_{\mathrm{q}}^{\prime}=1.22 \mathrm{pu}, \mathrm{V}_{\mathrm{b}}=1 \mathrm{pu}$

It can be seen from the figure that the at output electrical power $0.8 \mathrm{pu}$ the rotor angle of non-salient pole is 31.64 degree whereas for the salient pole is 45.35 degree. The maximum value of the output power for salient pole is higher than that of non-salient pole.

The derived equation will be further investigate and compared the critical clearing time by implementing in MATLAB/SIMULINK.

\section{RESULTS}

Consider the diagram of sample system is shown in Fig. 1a. It is considered that three phase fault appears at line 2 near bus i and the fault is cleared by opening both circuit breakers. Figure 4 shows the rotor angle of the system with clearing time $\left(\mathrm{t}_{\mathrm{cl}}\right)$ for $170 \mathrm{~m} \mathrm{sec}$.

Based on the simulation, the critical clearing time of the system with synchronous generator of non-salient pole is around 174-175 m sec where that of the salient pole is $175-176 \mathrm{~m} \mathrm{sec}$. Figure 5 shows the swing curve of the system with $t_{\mathrm{cl}}=175 \mathrm{~m} \mathrm{sec}$.

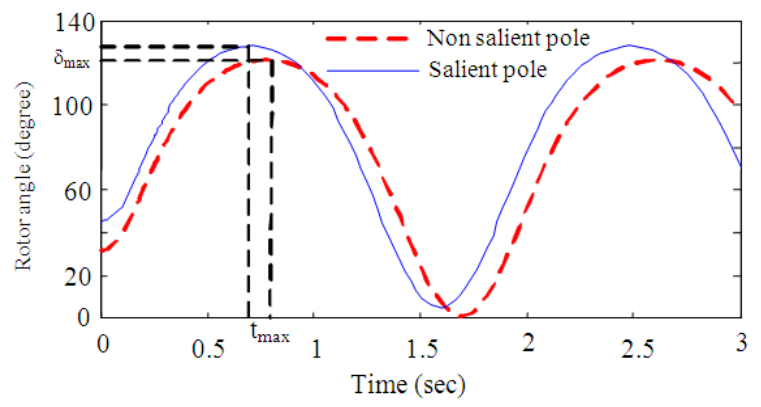

Fig. 4: Swing curve of the system for $t_{\mathrm{cl}}=170 \mathrm{msec}$

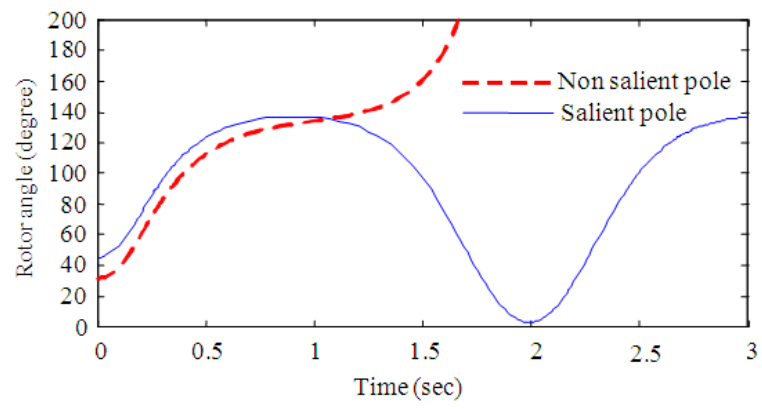

Fig. 5: Swing curve of the system for $t_{c l}=175 \mathrm{msec}$

\section{DISCUSSION}

There are three interesting simulation results on this investigation. First, the swing curve of salient pole and non-salient pole are obviously different. With $\mathrm{t}_{\mathrm{cl}}=$ $170 \mathrm{~m} \mathrm{sec}$, the maximum generator rotor angle $\left(\delta_{\max }\right)$ of non-salient pole type is around 121.19 whereas the salient pole type is around 127.71. Second, the time of maximum rotor angle $\left(\mathrm{t}_{\max }\right)$ of salient pole is less than that of non-salient pole as can be seen in Fig. 3. Third, the critical clearing time of different types of synchronous generator model are slightly different.

\section{CONCLUSION}

This paper investigated the critical clearing time of the system equipped with different types of synchronous generator. The mathematical models are symmetrically derived. There are three interesting simulation results on this paper. First, the maximum generator rotor angle of salient pole and non-salient pole are significantly different. Second, the time of maximum rotor angle $\left(\mathrm{t}_{\max }\right)$ of salient pole is less than that of non-salient pole. Third, the critical clearing time of different types of rotor pole are insignificantly different. It can be confirmed that with critical clearing time evaluation, the mathematical model of 
synchronous generator in non-salient is not only simpler but also able to be applied for the system with salient pole.

\section{REFERENCES}

Al-Husban, A.N., 2009. An eigenstructure assignment for a static synchronous compensator. Am. J. Eng. Applied Sci., 2: 812-816. DOI: 10.3844/ajeassp.2009.812.816

Darabi, A., S.A. Soleamani and A. Hassannia, 2008. Fuzzy based digital automatic voltage regulator of a synchronous generator with unbalanced loads. Am. J. Eng. Applied Sci., 1: 280-286. DOI: 10.3844/ajeassp.2008.280.286

Kumkratug, P., 2010. Application of interline power flow controller to increase transient stability of power system. J. Comput. Sci., 6: 1490-1493. DOI: 10.3844/jcssp.2010.1490.1493

Kumkratug, P., 2011. optimal control design of static synchronous series compensator for damping power system oscillation. J. Comput. Sci., 7: 844848. DOI: $10.3844 /$ jcssp.2011.844.848
Magaji, N. and M.W. Mustafa, 2009. Optimal thyristor control series capacitor neuro-controller for damping oscillations. J. Comput. Sci., 5: 980-987. DOI: $10.3844 /$ jcssp. 2009.980 .987

Osuwa, J.C. and E.C. Igwiro, 2010. Uninterruptible power supply using solar rechargeable battery. Physics. Int., 1: 77-82. DOI: 10.3844/pisp.2010.77.82

Santos, S.P.Y., E. Delbone, E.F. Carvalho and L.N. Martins, 2010. Synchronous generator disturbance provoked by induction motor starting. Am. J. Applied Sci., 7: 962-968. DOI: 10.3844/ajassp.2010.962.968

Taher, S.A., R. Hematti, A. Abdolalipour and M. Nemati, 2008. Decentralized controller design for static synchronous compensator using robust quantitative feedback theory method. Am. J. Eng. Applied Sci., 1: 66-75. DOI: 10.3844/ajeassp.2008.66.75

Zarate-Minano, R., T.V. Custsem, F., Milano and A.J. Conejo, 2010. Securing transient stability using time-domain simulations within an optimal power flow. IEEE Trans. Power Syst., 25: 243-253. DOI: 10.1109/TPWRS.2009.2030369 